\title{
Understanding Global Citizenship Levels of Turkish Erasmus Students in Poland from Different Variables
}

\author{
Kadir Karatekin \\ Kastamonu University, Faculty of Education, Kastamonu, Turkey \\ Muhammed Hayati Taban \\ Kastamonu University, School of Foreign Languages, Kastamonu, Turkey
}

\begin{abstract}
Global citizenship has been a phenomenon at presence since Kant's Perpetual Peace (1795) though it is seemed nascent. The concept defined as "world citizen by Kant, has been widely used as "post national citizenship", "cosmopolitan citizenship" and "global citizenship" as a solution to the problems of the global age. Sociology, International Relations and Educational Sciences emphasizes different aspects of global citizenship while all of them champion the effect of study abroad experience on global citizenship. In other words, study abroad experience helps awareness of the global problems, produce solutions for these problems and finally take actions at the global level. Hence forth, Erasmus program which is one of the most extensive study abroad programs is considered to contribute to personal awareness process for responsibilities beyond his own society. From this point of view this study conducted through descriptive survey model aims to understand the effect of different variables on the global citizenship levels of Turkish Erasmus students in Poland. In line with this aim, 201 Turkish Erasmus students in Poland were conducted "global citizenship scale" developed by Morais \& Ogden (2010). Findings suggest that Turkish Erasmus students have an intermediate level of global citizenship, and get the lowest level from global civic engagement sub dimension. Also it is understood that some variables have an impact on global citizenship.
\end{abstract}

Keywords: Global Citizenship, Turkish Erasmus Students, Poland

\section{Introduction}

If we need to define one phenomena for world history and international relations in recent era, it will be globalization. The shrinking of the world, appearance of supra national institutions like the EU and the extending borders of money and trade circulation are both causes and outcomes of this still working process. With the rise of globalization the global citizenship concept have started to be discussed. Global citizenship definition covers the awareness of one's role as a citizen of this wide world, respecting diversity, understanding how the world works, being reactionary against social injustice, being engaged in different communities ranging from local to global, being ready for any kind of action that aims to make world more equal and sustainable and feeling the responsibility of one's actions (Oxfam, 2006). Thought in this context, Erasmus program with its diversity, scope and aims can be considered as an effort to educate global citizens.

Turkey sees the EU as a way of adapting and integrating to globalization. EU membership policy has been one of the main pillars of Turkish Foreign Policy. Turkey's EU experience has a long history dating back to 1959. Since then Turkey has been aiming to be a full member of the EU. And there have been official accession negotiations since 2005. But Turkey's involvement in Erasmus program had started in 2004. After 2004 starting from big universities in Turkey, almost all universities began to benefit from this exchange program.

Increasing number of outgoing Turkish Erasmus students has opened the way for various studies focusing on different perspectives; the efficiency of the program for Turkey's integration to the EU, the outcomes of Erasmus experience of Turkish students, the comparison of Turkish students with the host country's students, etc. The majority of the studies have focused on those students who have just completed their Erasmus experience. Yagci et al. have, for example, carried out satisfaction survey (daily life, academic life, student affairs etc.) with Hacettepe University students who have Erasmus 
experience. Şahin (2007) similarly has looked into the questions whether students have achieved their goals set before the Erasmus experience and what kind of changes have occurred after the experience. Bulut (2008) also has studied the efficiency of the Erasmus program in terms of Turkish students. Demir and Demir (2009) have focused on the contribution of the program to the students at Erciyes University Faculty of Education. They have highlighted the benefits of the program to students' personal development and problem solving skills. Sarı and Aktan (2010) and Onder and Balci (2010) have also tried to uncover opinions of students about Erasmus program.

This study aims to understand Turkish Erasmus students' global citizenship level. What makes this study different from previous studies is that the data collected through fieldwork and Morais and Ogden's global citizenship scale was carried out during Turkish students' Erasmus experience in Poland. The Turkish version of the scale was already used by doing validity and reliability tests by Şahin and Çermik (2011). Looking through the literature, it will be the first study carried out with Turkish Erasmus students during their experience.

To uncover what kind of variables have an impact on Turkish Erasmus students' level of global citizenship, these hypotheses will be tested:

$\mathrm{H} 1$ : There is a positive correlation between being a membership of a NGO, being interested in politics and global citizenship level.

H2: Those proving Turkey's membership to the EU have a higher level of global citizenship.

H3: Gender makes a difference in global citizenship level.

H4: The more family income a student have, the better s/he has a global citizenship level.

\section{Method}

\section{Research Model}

In this study survey model, one of the quantitative research methods is used to understand global citizenship levels of Turkish Erasmus students in Poland in terms of various variables. Survey model is a quantitative research method that helps to reveal the opinion, behavior or attitude of a sample about an issue or situation (Creswell,2012)

\section{Study Group}

The study group is composed of 201 Turkish Erasmus students in Poland at University of Warsaw in Warsaw (the biggest and the capital city of Poland), Tischner European University in Krakow (the second biggest city of Poland) and University of Information Technology and Management in Rzeszow. Some demographic information of the study group is given the tables below

Table 1. Gender distribution of the study group

\begin{tabular}{|c|c|c|c|c|c|c|}
\hline \multirow{3}{*}{ Participants } & \multicolumn{6}{|c|}{ Gender } \\
\hline & \multicolumn{2}{|c|}{ Female } & \multicolumn{2}{|c|}{ Male } & \multicolumn{2}{|c|}{ Total } \\
\hline & $f$ & $\%$ & $f$ & $\%$ & $f$ & $\%$ \\
\hline Turkish Erasmus Students & 70 & 34,8 & 131 & 65,2 & 201 & 100 \\
\hline
\end{tabular}

$34,8 \%$ of 201 participants of Turkish Erasmus students is female and $65,2 \%$ of that is male.

Table 2. Age distribution of the study group.

\begin{tabular}{lllllllll}
\hline \multirow{2}{*}{ Participants } & \multicolumn{2}{l}{ Age } & & & & & \\
\cline { 2 - 8 } & $18-19$ & & $20-22$ & & 23 and over & Total \\
\cline { 2 - 8 } & $\mathrm{f}$ & $\%$ & $\mathrm{f}$ & $\%$ & $\mathrm{f}$ & $\%$ & $\mathrm{f}$ & $\%$ \\
\hline Turkish Erasmus Students & 14 & 7 & 111 & 55,2 & 76 & 37,8 & 201 & 100 \\
\hline
\end{tabular}


The biggest majority of the participants (55,2\%) belongs to $20-22$ ages while the lowest participation belongs to $18-19$ ages $(7,8 \%)$.

Table 3. Distribution of the study group by mother's education level

\begin{tabular}{lll}
\hline \multirow{2}{*}{ Mother's Education Level } & \multicolumn{2}{l}{ Turkish Erasmus Students } \\
\cline { 2 - 3 } & $\mathrm{f}$ & $\%$ \\
\hline Illiterate & 8 & 4 \\
\hline Only literate & 10 & 5 \\
\hline Primary School Graduate & 48 & 23,9 \\
\hline Secondary School Graduate & 24 & 11,9 \\
\hline High School Graduate & 69 & 34,3 \\
\hline University graduate and above & 42 & 20,9 \\
\hline Total & 201 & 100 \\
\hline
\end{tabular}

There are 8 students whose mother is illiterate and majority of students' mother is high school graduate $(34,3 \%)$.

Table 4. Distribution of the study group by father's education level

\begin{tabular}{lll}
\hline \multirow{2}{*}{ Father's Education Level } & \multicolumn{2}{l}{ Turkish Erasmus Students } \\
& & \\
\cline { 2 - 3 } & & \\
\cline { 2 - 3 } & $\mathrm{f}$ & $\%$ \\
\hline Illiterate & - & - \\
\hline Only literate & 4 & 2 \\
\hline Primary School Graduate & 43 & 21,4 \\
\hline Secondary School Graduate & 23 & 11,4 \\
\hline High School Graduate & 62 & 30,8 \\
\hline University graduate and above & 69 & 34,3 \\
\hline Total & 201 & 100 \\
\hline
\end{tabular}

There is no student whose father is illiterate and majority of students' father is university graduate $(34,3 \%)$. When Table 3. and Table 4. taken into consideration, it can be seen that more than half of the students' parents are not university graduate. This finding emphasizes the importance of Erasmus for Turkish students.

Table 5. Distribution of the study group by monthly family income 


\begin{tabular}{lcc}
\hline $1001-2000 \mathrm{TL}$ & 44 & 21,9 \\
\hline $2001-3000 \mathrm{TL}$ & 55 & 27,4 \\
\hline $3001-4000 \mathrm{TL}$ & 45 & 22,4 \\
\hline $4001+\mathrm{TL}$ & 57 & 28,4 \\
\hline Total & 201 & 100 \\
\hline
\end{tabular}

There is a homogeny distribution in income level for Turkish Erasmus students: $21,9 \%$ of the study group has 1001-2000 TL monthly income; $27,4 \%$ has $2001-3000$ TL monthly income; $22,4 \%$ has $3001-4000$ TL monthly income and $28,4 \%$ has $4001+$ TL monthly income.

Table 6. Distribution of the study group by being a member of a nongovernmental organization

\begin{tabular}{|c|c|c|c|c|c|c|}
\hline \multirow[t]{2}{*}{ Being a Member of a Nongovernmental Organization } & \multicolumn{2}{|c|}{ Yes } & \multicolumn{2}{|l|}{ No } & \multicolumn{2}{|c|}{ Total } \\
\hline & $f$ & $\%$ & $f$ & $\%$ & $\mathrm{~F}$ & $\%$ \\
\hline Turkish Erasmus Students & 41 & 20,4 & 160 & 79,6 & 201 & 100 \\
\hline
\end{tabular}

The number of Turkish Erasmus students who are a member of a NGO is only 41 (20,4\%).

Table 7. Distribution of the study group by the level of interest in politics

\begin{tabular}{lll}
\hline \multirow{2}{*}{ The level of interest in politics } & \multicolumn{2}{l}{ Turkish Erasmus Students } \\
\cline { 2 - 3 } & $\mathrm{f}$ & $\%$ \\
\hline None & 22 & 10,9 \\
\hline Little & 42 & 20,9 \\
\hline Some & 79 & 39,3 \\
\hline Much & 58 & 28,9 \\
\hline Total & 201 & 100
\end{tabular}

The majority of Turkish Erasmus students feel interested in politics ("some" = 79 and "much "= 58) while 10,9 \% of them has no interest in politics.

Table 8. Distribution of the study group by proving Turkey's EU membership.

\begin{tabular}{|c|c|c|c|c|c|c|c|c|}
\hline \multirow[t]{2}{*}{ The attitude towards Turkey's EU membership } & \multicolumn{2}{|l|}{ Yes } & \multicolumn{2}{|l|}{ No } & \multicolumn{2}{|c|}{ No Idea } & \multicolumn{2}{|c|}{ Total } \\
\hline & $f$ & $\%$ & $\mathrm{f}$ & $\%$ & $\mathrm{f}$ & $\%$ & $\mathrm{f}$ & $\%$ \\
\hline Turkish Erasmus Students & 127 & 63,2 & 52 & 25,9 & 22 & 10,9 & 201 & 100 \\
\hline
\end{tabular}

The rate of those students who supports Turkey's EU membership is $63,2 \%$ while that of who doesn't support Turkey's EU membership is $25,9 \%$ and $10,9 \%$ of the students has no idea about the process.

\section{Data Collection Tool}


A personal information form consisting variables considered to be influential on global citizenship level, and Global Citizenship Scale developed by Morais and Ogden (2010) were used to understand Turkish Erasmus students' global citizenship level. The Turkish version of the Global Citizenship Scale was adapted by Akın, A., Sarıçam, H., Akın, Ü., Yıldız, B., Demir, T., and Kaya, M. (2014). The Global Citizenship Scale has three subdimensions : Social responsibility, Global competence and Global civic engagement. The coefficients of internal consistency reliability of the scale are as follows for the subdimensions: .60 for global responsibility, .69 for global competence and .86 for global civic engagement. It can be said that these results proves the scale to be reliable.

\section{Data Analysis}

Data obtained from the study was analyzed via SPSS (Statistical Package for the Social Sciences) program. The answers to the 5 point likert scale have been interpreted as seen in the table below.

Table 9. Score intervals used to interpret the averages.

\begin{tabular}{lll}
\hline Score Intervals & Grading & Interpretation \\
\hline $1.00-1,80$ & Strongly Disagree & Very inadequate \\
\hline $1,81-2,60$ & Disagree & Inadequate \\
\hline $2,61-3,40$ & Neutral & Average \\
\hline $3,41-4,20$ & Agree & Satisfactory \\
\hline $4,21-5,00$ & Strongly Agree & Very Satisfactory \\
\hline
\end{tabular}

\section{Findings And Comments}

Table 10. Global citizenship levels of Turkish Erasmus students.

\begin{tabular}{llll}
\hline Global Citizenship Scale Subdimensions & \multicolumn{2}{l}{ Turkish Erasmus Students } & \\
\cline { 2 - 4 } & $\mathrm{N}$ & $\overline{\mathrm{X}}$ & $\mathrm{S}$ \\
\hline Social Responsibility & 201 & 3,72 &, 505 \\
\hline Global Competence & 201 & 3,502 \\
\hline Global Civic Engagement & 201 & 3,10 &, 606 \\
\hline TOTAL & & &, 398 \\
\hline
\end{tabular}

It is seen from Table 10. that Turkish Erasmus students have an average $(3,34)$ global citizenship score from the overall of the scale. Also, Turkish Erasmus students' social responsibility score is average $(3,72)$ and it is higher than their global competence score $(3,50)$. This finding suggests that Turkish Erasmus students have enough faith in taking responsibility but they don't see themselves competent enough to go into action. What is also important to note that the lowest score of Turkish Erasmus students belongs to global civic engagement dimension $(3,10)$, which implies that they don't have strong belief in actions requiring engagements to solve global problems.

Table 11. t-test results of Turkish Erasmus students' global citizenship levels by gender variable

\begin{tabular}{|c|c|c|c|c|c|c|c|}
\hline Global Citizenship and Subdimensions & Gender & $\mathrm{N}$ & $\overline{\mathrm{X}}$ & S & $\mathrm{sd}$ & $\mathrm{t}$ & $p$ \\
\hline \multirow[t]{2}{*}{ Social Responsibility } & Female & 70 & 23.55 & 3.88 & 199 & 3,117 & ,002 \\
\hline & Male & 131 & 21.67 & 4.18 & & & \\
\hline
\end{tabular}




\begin{tabular}{|c|c|c|c|c|c|c|c|}
\hline \multirow[t]{2}{*}{ Global Competence } & Female & 70 & 30.48 & 4.18 & \multirow[t]{2}{*}{199} & \multirow[t]{2}{*}{$-2,451$} & \multirow[t]{2}{*}{015} \\
\hline & Male & 131 & 32.10 & 4.61 & & & \\
\hline \multirow[t]{2}{*}{ Global Civic Engagement } & Female & 70 & 46.41 & 8.10 & \multirow[t]{2}{*}{199} & \multirow[t]{2}{*}{,- 123} & \multirow[t]{2}{*}{902} \\
\hline & Male & 131 & 46.58 & 9.60 & & & \\
\hline \multirow[t]{2}{*}{ Global Citizenship } & Female & 70 & 100.45 & 11.47 & \multirow[t]{2}{*}{199} & \multirow[t]{2}{*}{,055 } & \multirow[t]{2}{*}{956} \\
\hline & Male & 131 & 100.35 & 12.26 & & & \\
\hline
\end{tabular}

Table 11. shows that female Turkish Erasmus students feel more social responsibility while male Turkish Erasmus students feel more globally competent. As for global citizenship overall score and global civic engagement dimension, not any significant difference has been found.

Table 12. One way variant analysis of Turkish Erasmus students' global citizenship scores in terms of income level

\begin{tabular}{|c|c|c|c|c|c|c|c|}
\hline Subdimensions & $\begin{array}{l}\text { Variance } \\
\text { Source }\end{array}$ & KT & sd & $\mathrm{KO}$ & $\mathrm{F}$ & $p$ & $\begin{array}{l}\text { Difference } \\
\text { Scheffe }\end{array}$ \\
\hline \multirow{3}{*}{$\begin{array}{l}\text { Social } \\
\text { Responsibility }\end{array}$} & $\begin{array}{l}\text { Between } \\
\text { groups }\end{array}$ & 116.5449 & 4 & 38.848 & 2.272 & 0.081 & \multirow[t]{3}{*}{-} \\
\hline & Within groups & 3367.783 & 197 & 17.095 & & & \\
\hline & Total & 3484.328 & 201 & & & & \\
\hline \multirow{3}{*}{$\begin{array}{l}\text { Global } \\
\text { Competence }\end{array}$} & $\begin{array}{l}\text { Between } \\
\text { groups }\end{array}$ & 20.454 & 4 & 6.818 & 0.329 & 0.803 & \multirow[t]{3}{*}{-} \\
\hline & Within groups & 4071.436 & 197 & 20.667 & & & \\
\hline & Total & 4091.890 & 201 & & & & \\
\hline \multirow{3}{*}{$\begin{array}{l}\text { Global Civic } \\
\text { Engagement }\end{array}$} & $\begin{array}{l}\text { Between } \\
\text { groups }\end{array}$ & 354.526 & 4 & 118.175 & 1.438 & 0.232 & \multirow[t]{3}{*}{-} \\
\hline & Within groups & 16181.622 & 197 & 82.140 & & & \\
\hline & Total & 16536.149 & 201 & & & & \\
\hline \multirow{3}{*}{ Global Citizenship } & $\begin{array}{l}\text { Between } \\
\text { groups }\end{array}$ & 573.986 & 4 & 191.328 & 1.343 & 0.261 & \multirow[t]{3}{*}{-} \\
\hline & Within groups & 28057.963 & 197 & 142.42 & & & \\
\hline & Total & 28631.950 & 201 & & & & \\
\hline
\end{tabular}

No significance has been found between income level of Turkish Erasmus student and their global citizenship overall scores and other subdimensions scores (Table 12.). This means that income level has no influence on students' global citizenship levels.

Table 13. $t$ test results of the impact of university education on students' global citizenship level.

\begin{tabular}{llllllll}
\hline $\begin{array}{l}\text { Global Citizenship and } \\
\text { Subdimensions }\end{array}$ & $\begin{array}{l}\text { The impact } \\
\text { of university } \\
\text { education }\end{array}$ & $\mathrm{N}$ & $\overline{\mathrm{X}}$ & $\mathrm{S}$ & $\mathrm{sd}$ & $\mathrm{t}$ & $\mathrm{p}$ \\
\hline Social Responsibility & Yes & 145 & 22,37 & 4,27 & 199 &, 278 &, 781 \\
& No & 56 & 22,19 & 3,93 & & & \\
\cline { 2 - 6 } & Yes & 145 & 32,05 & 4,34 & 199 & 2,734 &, 007 \\
\hline Global Competence & No & 56 & 30,16 & 4,70 & & &
\end{tabular}




\begin{tabular}{|c|c|c|c|c|c|c|c|}
\hline \multirow[t]{2}{*}{ Global Civic Engagement } & Yes & 145 & 47,79 & 8,70 & \multirow[t]{2}{*}{199} & \multirow[t]{2}{*}{3,264} & \multirow[t]{2}{*}{,001 } \\
\hline & No & 56 & 43,23 & 9,33 & & & \\
\hline \multirow[t]{2}{*}{ Global Citizenship } & Yes & 145 & 102,24 & 12,04 & \multirow[t]{2}{*}{199} & \multirow[t]{2}{*}{3,644} & \multirow[t]{2}{*}{,000 } \\
\hline & No & 56 & 95,58 & 10,40 & & & \\
\hline
\end{tabular}

As seen in Table 14. except from social responsibility dimension, there is a significance between student's education experience in Poland and their global citizenship levels. In other words, it can be emphasized that the Erasmus education they get in Poland have a positive impact on Turkish Erasmus students' global citizenship levels. It should also be highlighted that the big majority (145 out of 201) believes that the education they get in Poland have an impact on their global citizenship.

Table 14. $t$ test results of the impact of being a member of a NGO on students' global citizenship level

\begin{tabular}{|c|c|c|c|c|c|c|c|}
\hline Global Citizenship and Subdimensions & $\begin{array}{l}\text { NGO } \\
\text { Membership }\end{array}$ & $\mathrm{N}$ & $\overline{\mathrm{X}}$ & S & $\mathrm{sd}$ & $t$ & $p$ \\
\hline \multirow[t]{2}{*}{ Social Responsibility } & Yes & 41 & 22,78 & 3,95 & 199 & ,777 & ,438 \\
\hline & No & 60 & 22,21 & 4,23 & & & \\
\hline \multirow[t]{2}{*}{ Global Competence } & Yes & 41 & 32,39 & 5,68 & 199 & 1,348 & ,179 \\
\hline & No & 60 & 31,32 & 4,16 & & & \\
\hline \multirow[t]{2}{*}{ Global Civic Engagement } & Yes & 41 & 48,87 & 10,11 & 199 & 1,871 & ,063 \\
\hline & No & 60 & 45,91 & 8,74 & & & \\
\hline \multirow[t]{2}{*}{ Global Citizenship } & Yes & 41 & 104,04 & 11,86 & 199 & 2,214 & ,028 \\
\hline & No & 60 & 99,45 & 11,84 & & & \\
\hline
\end{tabular}

Table 14. shows that there is no significance between subdimensions of global citizenship and Turkish Erasmus students global citizenship levels. However it is also seen that those students who are a member of a NGO have higher overall global citizenship score that those who aren't.

Table 15. One way variant analysis of Turkish Erasmus students' global citizenship scores in terms of interest in politics.

\begin{tabular}{|c|c|c|c|c|c|c|c|}
\hline Subdimensions & Variance Source & KT & sd & $\mathrm{KO}$ & $\mathrm{F}$ & $p$ & $\begin{array}{l}\text { Difference } \\
\text { Scheffe }\end{array}$ \\
\hline \multirow{3}{*}{$\begin{array}{l}\text { Social } \\
\text { Responsibility }\end{array}$} & Between groups & 50.580 & 3 & 16.860 & \multirow[t]{3}{*}{0.967} & \multirow[t]{3}{*}{0.409} & \\
\hline & Within groups & 3433.747 & 197 & 17.430 & & & - \\
\hline & Total & 3484.328 & 200 & & & & \\
\hline \multirow{3}{*}{ Global Competence } & Between groups & 185.706 & 3 & 61.902 & \multirow[t]{3}{*}{3.121} & \multirow[t]{3}{*}{0.02} & \\
\hline & Within groups & 3906.183 & 197 & 19.828 & & & Much-None \\
\hline & Total & 4091.890 & 200 & & & & \\
\hline \multirow{3}{*}{$\begin{array}{l}\text { Global } \\
\text { Engagement }\end{array}$} & Between groups & 390.352 & 3 & 130.117 & \multirow[t]{3}{*}{1.587} & \multirow[t]{3}{*}{0.193} & \\
\hline & Within groups & 16145.796 & 197 & 81.958 & & & -- \\
\hline & Total & 16536.149 & 200 & & & & \\
\hline \multirow{3}{*}{ Global Citizenship } & Between groups & 1329.896 & 3 & 443.298 & \multirow[t]{3}{*}{3.198} & \multirow[t]{3}{*}{0.02} & \multirow[t]{3}{*}{ Much-None } \\
\hline & Within groups & 27302.053 & 197 & 138.589 & & & \\
\hline & Total & 28631.950 & 200 & & & & \\
\hline
\end{tabular}


It has been found that there is a significance between overall global citizenship and global civic engagement scores and students' interest in politics (Table 15). In other words, those students who are interested in politics tend to have a better sense of global citizenship and feel more globally competent.

Table 16. One way variant analysis of Turkish Erasmus students' global citizenship scores in terms of proving Turkey's EU membership.

\begin{tabular}{|c|c|c|c|c|c|c|c|}
\hline $\begin{array}{l}\text { Global Citizenship } \\
\text { Subdimensions }\end{array}$ & Variance Source & KT & sd & $\mathrm{KO}$ & $\mathrm{F}$ & $p$ & $\begin{array}{l}\text { Difference } \\
\text { Scheffe }\end{array}$ \\
\hline \multirow{3}{*}{$\begin{array}{l}\text { Social } \\
\text { Responsibility }\end{array}$} & Between groups & 113.468 & 3 & 56.734 & \multirow[t]{3}{*}{3.332} & 0.03 & \multirow{3}{*}{$1-2$} \\
\hline & Within groups & 3370.859 & 198 & 17.024 & & & \\
\hline & Total & 3484.328 & 201 & & & & \\
\hline \multirow{3}{*}{$\begin{array}{l}\text { Global } \\
\text { Competence }\end{array}$} & Between groups & 101.234 & 3 & 50.617 & \multirow[t]{3}{*}{2.511} & 0.08 & \multirow{3}{*}{--} \\
\hline & Within groups & 3990.655 & 198 & 20.154 & & & \\
\hline & Total & 4091.890 & 201 & & & & \\
\hline \multirow{3}{*}{$\begin{array}{l}\text { Global Civic } \\
\text { Engagement }\end{array}$} & Between groups & 115.154 & 3 & 57.577 & \multirow[t]{3}{*}{0.694} & 0.50 & \multirow{3}{*}{--} \\
\hline & Within groups & 16420.994 & 198 & 82.934 & & & \\
\hline & Total & 16536.149 & 201 & & & & \\
\hline \multirow{3}{*}{ Global Citizenship } & Between groups & 432.508 & 3 & 216.254 & \multirow[t]{3}{*}{1.518} & 0.22 & \multirow{3}{*}{--} \\
\hline & Within groups & 28199.441 & 198 & 142.421 & & & \\
\hline & Total & 28631.950 & 201 & & & & \\
\hline
\end{tabular}

Table 16. gives us that significance is only seen between social responsibility dimension and those students who prove the Turkey's EU membership. In other words students who wish Turkey to be a member country feel more socially responsible than those who don't.

\section{Results, Discussion And Recommendations}

In this study these hypotheses have been tested;

$\mathrm{H} 1$ : There is a positive correlation between being a membership of a NGO, being interested in politics and global citizenship level.

H2: Those proving Turkey's membership to the EU have a higher level of global citizenship.

H3: Gender makes a difference in global citizenship level.

H4: The more family income a student has, the better s/he has a global citizenship level

$\mathrm{H} 1$ : There is a positive correlation between being a membership of a NGO, being interested in politics and global citizenship level: True

It has been found in Table 15. that there is a significance between overall global citizenship and global civic engagement scores and students' interest in politics In other words, those students who are interested in politics tend to have a better sense of global citizenship and feel more globally competent. Have an interest in politics can be said to be one of the perquisites of global citizenship. In other words, someone who is interested in politics to some degree will also be aware of global problems.

As for being a member of NGO, Table 14. shows that there is no significance between subdimensions of global citizenship and Turkish Erasmus students' global citizenship levels. However it is also seen that those students who are a member of a NGO have higher overall global citizenship score that those who aren't. There many NGOs that have different functions and scope ranging from local districts to global. The type of NGOs that Turkish young people tend to be a member and those who don't tend to be a member may be analyzed in further studies. This way it will be better to understand Turkish young peoples' attitude towards NGOs.

H2: Those proving Turkey's membership to the EU have a higher level of global citizenship: Partially True. 
Table 16. gives us that significance is only seen between social responsibility dimension and those students who prove the Turkey's EU membership. In other words students who wish Turkey to be a member country feel more socially responsible than those who don't. Normally, it is expected that there would be a strong correlation between those who proves Turkey's membership and global citizenship levels. But correlation only exists in social responsibility dimension. Other dimensions (global competence and global civic engagement) and overall global citizenship score have no correlation with wish to Turkey's membership.

On the other hand, the rate of Turkish Erasmus students who proves Turkey's membership (127 out of 201,63,2\%) is higher than Turkish public opinion (in 2010 42\%, in 2012 36\%, in 2013 38\%) (EU Commission Standard Eurobarometer 74,2010, EU Commission Standard Eurobarometer 79, 2013). Here it can be explained that the Turkish Erasmus students have known "the other", tried to understand Europe and embrace European values to some extent. Indeed, many Europeans see the EU as "free circulation", "education and work freedom" while it is considered by many Turks as "economic welfare", social protection", "influence in the world" (EU Commission Standard Eurobarometer EB 81 2014). At this point, it is worth studying in detail exactly which rights, freedoms or privileges influenced Turkish Erasmus students.

\section{H3: Gender makes a difference in global citizenship level: Partially True}

Table 11. shows that female Turkish Erasmus students feel more social responsibility while male Turkish Erasmus students feel more globally competent. As for global citizenship overall score and global civic engagement dimension, not any significant difference has been found. These findings tell us that though gender seems to make some difference in global competence and social responsibility dimensions, there is not a big difference that make us think that gender is an important variable for global citizenship level.

\section{H4: The more family income a student has, the better s/he has a global citizenship level: False}

No significance has been found between income level of Turkish Erasmus student and their global citizenship overall scores and other subdimensions scores (Table 12.). This means that income level has no influence on students' global citizenship levels. To put in a different way, the income level which is one of the most important determinant of socio cultural level has no direct correlation with global citizenship. The wide scope of globalism is felt by almost every income groups. At least this is valid for our study group, Turkish Erasmus students To elaborate this finding, those students who are studying in private universities outside Turkey should be targeted in terms of global citizenship. This will help to understand those students who are in the top of income level and compare them to the others.

\section{Acknowledgements}

This research has been supported by Kastamonu University Scientific Research Projects Coordination Department. Project Number: KÜ-BAP01/2015.

\section{References}

[1] Akın, Ahmet., Sarıçam, H., Akın, Ü., Yıldız, B., Demir, T., \& Kaya, M. (2014). "The validity and reliability of the Turkish version of the Global Citizienship Scale." Paper presented at the 3rd International Symposium on Social Studies Education, April, 28-30, Ankara, Turkey

[2] Bulut, B. Ş. (2008). Students' and coorditators' views of the effectiveness of the Erasmus student exchange program at Middle East tecnical university, Master Thesis", Ortadoğu Teknik Üniversitesi, Ankara

[3] Creswell, J. (2012). Educational Research: Planning, Conducting, and Evaluating Quantitative and Qualitative Research (4. Edition). Boston: Pearson Education

[4] Demir, A., \& Demir, S. (2009). Erasmus Programının Kültürlerarası Diyalog Ve Etkileşim Açısından Değerlendirilmesi (Öğretmen Adaylarıyla Nitel Bir Çalışma). Journal Of International Social Research, 2(9)

[5] European Commission (2010) Standard Euro Barometer 74 Public Opition in the European Union, http://ec.europa.eu/public_opinion/archives/eb/eb74/eb74_publ_en.pdf,

[6] European Commission (2013) Standard Euro Barometer 79 Public Opinion in European Union, http://ec.europa.eu/public_opinion/archives/eb/eb79/eb79_first_en.pdf,

[7] European Commission (2014) Standard Euro Barometer 81 Public Opinion in European Union, http://ec.europa.eu/public_opinion/archives/eb/eb81/eb81_publ_en.pdf, 
[8] Morais, Duarte ve Ogden, Anthony (2010). Initial development and validation of the global citizenship scale. Journal of Studies in International Education, 15(5), 445-466.

[9] Oxfam Development Education Programme. (2006). Education for global citizenship: A guide for schools. Oxfam GB..

[10] Önder, R. K., Ve Balcı, A (2010). "Erasmus Öğrenci Öğrenim Hareketliliği Programının 2007 Yılında Programdan Yararlanan Türk Öğrenciler Üzerindeki Etkileri." Ankara Avrupa Çalışmaları Dergisi: 93

[11] Aktan, E., \& Sari, B. (2010). An Inquiry on Application Process of EU Erasmus Programme \& Students' Views Regarding Erasmus Programme of Student Exchange. European Perspectives on Internationalization, Exedra Special Issue,239, 268.

[12] Şahin, İ. (2007). Perceptions of Turkish exchange students of the European Union's Erasmus Program.Master Thesis. İstanbul: Boğaziçi Üniversitesi, Sosyal Bilimler Enstitüsü.

[13] Şahin, I. F., \& Çermik, F. (2014). Küresel Vatandaşlık Ölçeğinin Türkçeye Uyarlanması: Güvenirlik Ve Geçerlik Çalışması Turkish. Doğu Coğrafya Dergisi, 19(31), 207-218

[14] YAĞCl, E., Ekinci, C. E., Burgaz, B., Kelecioğlu, H., \& Ergene, T. (2007). Yurt dışına giden hacettepe üniversitesi erasmus öğrencilerinin memnuniyet düzeyleri. Hacettepe Üniversitesi Eğitim Fakültesi Dergisi, 33(33)

[15] ICSS sample page

[16] Please start writing from the second page!

[17] Font: Arial narrow, 9

[18] Spacing: before:0, after 6, single line

[19] One space after new headline

[20] Headline, bold and Intelligent Title Case

[21] (ie; not: ALL FOR CAPITAL, but: All for Capital) 